\title{
El reverso de la metafísica existenciaria de Ortega: la ética incapaz de Miguel Delibes*
}

\section{The reverse of the existential Metaphysics of Ortega: the incapable Ethics of Miguel Delibes}

\author{
ENRIQUE FERRARI \\ Fundación Escritura(s)
}

REsumEn. Ortega, aunque comprime su metafísica hasta formularla con su "Yo soy yo y mi circunstancia", no escribe apenas de esa circunstancia: de su condición y posibles aspectos. Del binomio con que explica la vida trabaja solo en la reacción del individuo, convertida su propuesta metafísica en una ética que confía en las fuerzas del sujeto para desarrollar su proyecto vital en cualquier entorno. Aún es de día, que publica Miguel Delibes en 1949, con la España de posguerra de fondo, puede leerse como una réplica a esta ética que Ortega llama de la ilusión: Su protagonista, ante una circunstancia abiertamente hostil, es incapaz de desarrollar el programa que quiere para su vida. La trama funciona como planteamiento de una ética que recalcula las posibilidades del individuo para realizarse en un entorno adverso.

Palabras clave: Aún es de día; razón vital; ética; picaresca; circunstancia.
Abstract. Ortega summarized his metaphysics with the formula: "I am I and my circumstances." But he does not write just about that circumstance: its nature and possible aspects. He focuses only on the reaction of the person: he turns his metaphysics in an ethic that relies on the forces the person to develop his project in any environment. Miguel Delibes published Aún es de dia in 1949 (in the Spanish postwar). The novel can be read as a reply to this ethic of illusion: Its protagonist is unable to develop the program he wants for its life because its circumstance is very hostile. The plot works as an ethical approach that recalculates the possibilities of the person to develop himself in an adverse environment.

Key words: Aún es de dia; vital reason; ethics; picaresque; circumstance.

\footnotetext{
* Este trabajo está incluido en el proyecto de investigación "El pensamiento del exilio español de 1939 y la construcción de una racionalidad política" (FFI2012-30822), financiado por el Ministerio de Economía y Competitividad en la convocatoria del Plan Nacional 2012.
} 
Para que haya decisión [en la vida] tiene que haber a la vez limitación y holgura, determinación relativa. Esto expreso con la categoría "circunstancias".

José Ortega y Gasset, ¿Qué es filosofia? (1929)

Muy lejos del optimismo metafísico de Ortega, que confía en la capacidad del hombre para desarrollar un proyecto vital en cualquier circunstancia, Delibes narra con Aún es de día (1949) la imposibilidad de vencer las dificultades del entorno en una atmósfera hostil, el desequilibrio de fuerzas que hace del intento un esfuerzo inútil. El tema de la novela es otro, cómo se impone la muerte sobre la vida, pero con la ficción que soporta la reflexión del narrador Delibes apunta también a una réplica a la metafísica existenciaria de la razón vital para recalcular las posibilidades de desarrollo de su protagonista en la España de la posguerra. Para sus dos primeras novelas toma un mismo punto de partida: la angustia que siente desde niño por la muerte, a la que le busca -aunque torpe, inseguro con los mecanismos de la narrativa- una historia en que apoyarla. Más directo con su primer libro, La sombra del ciprés es alargada, recurre a las memorias para explicar el protagonista su biografía como exemplum: a un tiempo novela de formación y novela de tesis, la vida de Pedro como ejemplificación de la teoría del desasimiento de su maestro para minimizar las consecuencias de la muerte. Pero para el segundo, obligado a buscar otra fórmula, otro argumento al menos, hace de la muerte solo la meta en un relato devastador que glosa la imagen cristiana para la vida o el mundo como valle de lágrimas. Al contrario que Pe- dro, Sebastián Ferrón, el personaje contrahecho de Aún es de día, no entiende como alternativa a su vida miserable una existencia apática, pusilánime, que lo distancie de todo. Intenta conformar su vida con unos parámetros sociales -con su mejora de empleo y su empeño por sacar de la pobreza a su familia-, hasta convencerse de que es incapaz de vencer tantos obstáculos, de que es mejor centrar sus esfuerzos en lo espiritual, en alimentar su alma para prepararse para la muerte: "En cinco meses tan solo -concluye el narrador- se había cansado de luchar; se había percatado de que no vale la pena colocar en la vida un excesivo interés. Por lo demás, todo ahora, observando a un lado y a otro, semejaba ser igual a entonces". ${ }^{1}$ A Delibes la biografía de Pedro en $L a$ sombra del ciprés le funciona de ejemplo positivo: resignado ante el peso de la muerte sobre la vida, se decide por una existencia sin lazos que pueda cortar luego la muerte, para no verse afectado. La biografía de Sebastián en Aún es de día le sirve, en cambio, de ejemplo negativo: sus intentos estériles por desenvolverse en una circunstancia adversa argumentan el error de su actitud combativa, de que fuera de una solución trascendental no hay posibilidad de hacer de la vida un proyecto en un entorno adverso.

Delibes, que apenas ha leído narrati$\mathrm{va}^{2}$ ni ha trabajado la técnica cuando empieza a escribir, vuelve impermeable su postura a los movimientos internos de la novela. No es capaz, antes de escribir $E l$ camino, de enriquecer su posición inicial con los elementos que surgen del propio desarrollo del relato, de completarla con 
matices, o con perspectivas. Pero el uso del narrador omnisciente en su segundo libro le permite al menos al protagonista cierta libertad de movimiento, un distanciamiento con la posición del propio Delibes, que abre el planteamiento en torno a la muerte como un absoluto a las vicisitudes de Sebastián Ferrón para sobrevivir en el día a día: en principio solo los andamios para plantear la tesis en la novela, pero con entidad suficiente para sugerir otra perspectiva en el diálogo en torno a las dificultades de la vida española en la posguerra, otro marco reflexivo o ideológico para la novela comprometida de los 50 que parece querer replicar el optimismo con que Ortega había formulado unos años antes la vida como quehacer. Porque a Sebastián, con un cociente intelectual bajo, el narrador le permite errores que no puede permitirse Pedro, a la vez narrador y protagonista, al contar su propia historia. Con lo que su trayectoria vital, en lugar de ir recta a su objetivo, empeñado en corroborar la futilidad de la vida, queda sinuosa, oscilante, valiosa en sí misma, como ejemplo o contraejemplo, pero rebasando el cauce que delimita el pensamiento o la actitud del narrador. Una vez fracasado su intento de redimirse socialmente, obvia las circunstancias reduciendo su yo al alma, para poder desarrollar un proyecto vital sin las trabas de su entorno (que tiene, como primer referente, su cuerpo deforme). Pero las vacilaciones iniciales de su protagonista -para una lectura menos endeudada con las preocupaciones del autor- obligan al narrador a detenerse en el funcionamiento de su vida como un proceso delibera- tivo, hecho de decisiones. Lo obligan, con el relato de sus estrategias para las distintas circunstancias, a tantear una metafísica existenciaria, de la vida como actividad, como proyecto. Cerca de Ortega, o al menos con él de referencia filosófica para perfilar sus intuiciones en torno a la existencia. Aunque Delibes en 1949 no ha leído (o lo ha hecho solo sucintamente) a Ortega.

Para sugerir su innovación en metafísica Ortega apunta dos imágenes. En sus primeros años escribe del arquero que dispara su flecha contra la diana, con la figura que toma de Aristóteles como analogía de la vida que decide su propio itinerario. En torno a 1932 escribe del náufrago, para justificar el uso de la cultura como útil, como respuesta a una necesidad, lo opuesto al culturalismo: Una imagen menos amable para la vida, pero con la que mantiene una actitud decidida, firme, ante la circunstancia: naufragar -insiste en ello- no es ahogarse, sino agitar los brazos para mantenerse a flote. ${ }^{3}$ Para su tesis -nuestro quehacer no nos es impuesto, sino que tenemos que elegírnoslo nosotros, escribe- ${ }^{4}$ no considera como opción la imposibilidad de afrontar ese programa vital, de que la circunstancia en que debe desarrollarse sea tan hostil que el sujeto tenga que renunciar, derrotado, a participar de la creación de su personaje. La única alternativa en que piensa es la delegación de esa responsabilidad, la opción de los que no quieren hacer el esfuerzo que exige ese quehacer constante. No la inviabilidad de elegir: la opresión del contorno mundanal, el combate desigual, que tampoco apunta en la 
sociología que escribe mucho después como apéndice de su metafísica, con "El hombre y la gente", con su noción de convivencia. En cambio, Delibes, unos años después, en una España devastada, busca en el reverso de esa libertad: se cuestiona el margen que le concede al sujeto la circunstancia (o determinadas circunstancias) para elegir. Cubre el espacio que Ortega (atento solo a cómo gestionar esa libertad del individuo) deja fuera: ${ }^{5}$ qué pasa cuando las circunstancias son del todo adversas, cuando toda elección resulta infructuosa porque no hay diálogo posible con el entorno. Aún es de día como otro enfoque complementario del de Ortega, con una reflexión que es primaria, anterior, aunque descuidada $\mathrm{u}$ obviada en la razón vital: No sobre cómo actuar con la libertad que le es impuesta al individuo, cómo desarrollar un programa vital. Sino si es posible siempre esa libertad, también bajo determinadas condiciones; qué margen de maniobra queda para ser autor o coautor de ese proyecto.

Aunque la comparativa aquí es solo el pie para una propuesta de lectura de Aún es de día alternativa a la más obvia que tutela el narrador. No tiene sentido un cuerpo a cuerpo: Son dos ámbitos distintos, o al menos dos modos de expresión distintos, con el planteamiento de Delibes (que hay que sonsacar a su novela) sin el rigor del discurso filosófico, sin querer para sí una argumentación impecable. Pero la correlación de metafísica y novela no es arbitraria. La dejó apuntada el propio Ortega, que explica su metafísica existencial dándole forma con sus imágenes a un campo semántico que merodea las formas y funciones de la narrativa: No llega a confiar en la capacidad de la literatura para aportar o trasmitir un conocimiento propio. Pero tuvo en su mano todos los elementos necesarios para hacer de la novela una pieza importante de su metafísica, como alternativa a la epistemología de los sistemas racionalistas con la que explicar el yo en su entorno, por su capacidad para mirar desde dentro, para simular la acción ejecutándose. ${ }^{6}$ Su comprensión de la vida como drama y una razón que en lugar de ser analítica es (o acaba siendo) histórica dejaban muy cerca el isomorfismo, la estructura adecuada de la novela para intentar darle forma a la vida. Aunque se queda solo con la imagen, con la comparación, para explicarle al lector, en una primera aproximación, el margen de libertad del sujeto en la toma de decisiones que afectan a su propia vida: como un novelista de sí mismo, señala varias veces, sin entender necesario apuntalarlo con una teoría de la literatura a la que le busca otras funciones. (En sus monografías sobre la novela, que escribe como excursos, limita su función a concentrar la atención del lector para sacarle más provecho al mensaje del escritor. Deudor de la noción moderna de la autonomía del arte, no puede ir más allá de un cierto sonambulismo fértil, por las resonancias vitales que le despierta al lector la lectura. Deja en suspenso, sin querer siquiera tantearlo, el recorrido que luego emprende Julián Marías, ${ }^{7}$ desde la novela existencial de Unamuno: como el modo de captar el carácter dinámico de la vida desde las hipótesis que construyen las vivencias ficcionales de los personajes). 
En cualquier caso, leída la metafísica como una ética: La de Ortega es esa ética de la ilusión que anuncia en la lección $\mathrm{X}$ de ¿Qué es filosofia? ${ }^{8}$ con la misión cada uno de conformar su vida: confiada en la capacidad de creación del hombre, de crearse a sí mismo, como alternativa a las éticas del deber. La de Delibes, en cambio, sería una ética incapaz, que reflexiona sobre la imposibilidad de decidir uno mismo con su propia vida, sobre lo estéril de cada decisión ante una circunstancia adversa, incapacitante. Escribe Ortega: "Nada debilita tanto los profundos resortes del viviente como el exceso de facilidades". Quiere a su sujeto moral náufrago, para forzarle a dar lo máximo de sí mismo, pero no entra en las características del escenario, que minusvalora, que ningunea como oponente serio. Delibes es más cauto, más pesimista: "Se sintió náufrago y abandonado en medio de aquel océano de humanidad que le envolvía -escribe de Sebastián con la mismo metáfora de Ortega-. Era aquel un mar espeso e inextricable, colmado de reconditeces, escollos y arrecifes; un mar difícil, donde suponía un esfuerzo de titanes sostenerse a flote" (p. 199). ${ }^{10}$

\section{La circunstancia como rival asequible: la ética de Ortega}

Lo vio Aranguren primero: Ortega no habla de ética porque su filosofía entera es una metafísica ética, porque aparecen fundidas su metafísica y su ética, con el hombre como constitutivamente moral por tener que hacer su vida, por tener que ser fiel a su proyecto. ${ }^{11}$ Con un quehacer que no es arbitrario. Otro enfoque -escri- be Lasaga- ${ }^{12}$ para la autonomía del sujeto moral: No la simplificación de Kant, al fundamentarla en una razón pura, con un apriori racional. Sino con la vida humana, también como apriori, al tener que decidir uno -por ser libre, sin una identidad constitutiva- los criterios con que dirigir su vida: qué posibilidades realiza, qué argumento quiere para sí mismo. Ortega no deja escrita una ética, pero en su metafísica busca un ethos de la excelencia, la perfección del ser. No el cumplimiento de unas normas (externas o internas), sino la fidelidad a la propia existencia: una moral que sea tonificante e inteligente, un tónico vital, explica Cerezo, "una cultura nutricia, elemental, que restaure la fuerza vital en lugar de deprimirla". ${ }^{13}$ Una cualidad deportiva, que se añade lujosamente, con ironía, sin patetismo alguno, a lo que es imprescindible: una exigencia propia, escribe Ortega en "No ser hombre ejemplar". ${ }^{14}$ Aunque no especifica nada para las condiciones más adversas.

Muy joven, en 1914, con Meditaciones del Quijote, Ortega pasa a limpio sus primeras reflexiones, las notas que ha escrito desde 1902 para la prensa. Le queda ecléctico, descompensado, con un prólogo demasiado largo, decididamente autónomo, y solo dos meditaciones (una de ellas preliminar), sin organización interna, sin voluntad tampoco de complementarse entre ellas. El origen del libro -cuya morfología final le cambia la publicación de Vida de don Quijote y Sancho de Unamuno- es un breve tratado sobre la novela: (en principio) un diálogo con la narrativa de Baroja que le queda desconectado del resto del libro, aunque enca- 
ja bien con esa primera producción suya que busca, con el análisis y la crítica de la literatura que le es afín, el tono de su filosofía, menos conformada al principio de lo que quiere hacer creer cuando mira atrás y reconstruye sus fórmulas iniciales, hinchándolas con su desarrollo posterior. El único punto en el que convergen las distintas direcciones del texto es la preocupación patriótica de Ortega, que apunta al destinatario: el lector español, al que le pide un cambio de actitud, sustituir el odio por el amor que entiende que hay tras el afán de comprensión, por la confianza en la ciencia y la filosofía. Una deontología hecha a saltos. Una propuesta ceñida a la teoría del conocimiento para la que señala una metodología que incorpora al método científico lo que él llama el modo de ver mediterráneo, cerca de la fenomenología: en lugar de los valores hieráticos que promocionó el idealismo, la reabsorción de la circunstancia: un afán de comprensión, de abrirse al otro, de querer convivir. Una replanteamiento más sofisticado de la estética espacial de su álter ego, Rubín de Cendoya, ${ }^{15}$ que desemboca en su réplica al idealismo con su "Yo soy yo y mi circunstancia": el vórtice de su metafísica planteado por primera vez, pero sin ningún desarrollo como ontología, interrumpida la explicación abruptamente para señalar dos circunstancias de la España de su tiempo: Baroja y Azorín. Al principio solo la premisa de su apuesta por una epistemología más cercana, solo la atención al espacio en el que (con el que) se desenvuelve un sujeto que no quiere saber nada de la conciencia, una cuestión espacial. Sin recorrido en Meditaciones del Quijote, pero, como fórmula, tan moldeable que en trabajos posteriores puede engordarla de contenido hasta encajar también su noción de la vida como un proyecto que debe desenvolverse en un entorno que uno no puede elegir. Una propuesta sugerente para una nueva ontología (si se la quiere llamar así) alejada de la idea de sustancia. Aunque poco armada; o al menos poco minuciosa en su desarrollo, sin más explicación que su idea central de la vida como tarea o como drama: la representación de su dinamicidad, frente a lo estático de la sustancia. Lo que ha dicho Marías: Una primera aproximación a un teoría metafísica de la vida humana; aunque, como apunta Pedro Cerezo, muy acentuado lo de primera aproximación, sin el sistema doctrinal que se le suma luego. ${ }^{16}$

Pero, aunque Ortega recordará a menudo su precocidad al vislumbrar una nueva comprensión de la vida, para contrarrestar el desarrollo más serio, más exhaustivo, de Heidegger, el planteamiento posterior de su metafísica deja de apoyarse en esa noción de circunstancia, ${ }^{17}$ de la que apenas vuelve a escribir: Para absorber en su propuesta existenciaria, en torno a 1930, ese entorno ( $\mathrm{el}$ mundo próximo en derredor) prefiere la imagen de un escenario, con la que, a pesar de todo, también se muestra muy cauto. ${ }^{18}$ En Meditaciones del Quijote, centrado en el conocimiento, la circunstancia aparece como posición. Contra la ubicuidad idealista, propone al lector una plena conciencia de su circunstancia para comunicarse con el universo: buscar en la circunstancia 
"el lugar acertado en la inmensa perspectiva del mundo". ${ }^{19}$ En principio la réplica a un conocimiento objetivista, los apuntes de una epistemología con que el autor justifica el tema de sus meditaciones ("las cosas más nimias"); pero que en la cadencia argumental del prólogo acaba apoyada (como si no fuera del todo consciente de ello) en una metafísica audaz. Concluye Ortega apresuradamente que la reabsorción de la circunstancia es el destino concreto del hombre, para lo que le busca un tono metafísico, disonante con el resto del libro: "Esta realidad circunstante -escribe- forma la otra mitad de mi persona: solo al través de él puedo integrarme y ser plenamente yo mismo", que simplifica inmediatamente después con su "Yo soy yo y mi circunstancia": ${ }^{20}$ Un camino que desanda al momento, de vuelta al Guadarrama y al Manzanares para ceñir sus meditaciones a los casos concretos, a sus propias circunstancias, sin necesidad de más preámbulo. Solo deja una definición mínima de qué es la circunstancia, lo contrario que los valores hieráticos de la cultura del XIX, lo que ha quedado fuera de la atención del culturalismo idealista: las cosas mudas que están en nuestro próximo derredor; la vida individual, lo inmediato. ${ }^{21}$ Como si le bastara el campo semántico común del término, que no matiza ni hincha en trabajos posteriores, con una terminología que mantiene solo como testigo de su anticipación en la filosofía europea del XX, para vincular sus trabajos más rigurosos de metafísica (a partir de 1929) con su sentencia rotunda de 1914, como si fueran su desarrollo expositivo. ${ }^{22}$ Pero incluso entonces es de- masiado conciso en su explicación de la vida como materia de su metafísica, de la que enseña solo sus trazos más gruesos, un esquema mínimo: La ilustración del espacio en el que tiene que desenvolverse el sujeto -el propio análisis de la circunstancia- le queda endeble, nada exhaustiva. Solo unos pocos parámetros para poder ubicar la acción -o, mejor, el talante que sugiere para la acción, muy cerca del esfuerzo deportivo- con lo que centra su propuesta. De la vida dice únicamente que es drama: de drao, que en griego significa actuar, ejecutar. Hacerse a sí misma. ${ }^{23}$ Faena poética, como la del dramaturgo o el novelista. ${ }^{24}$ Un género literario. Una obra de arte total: ${ }^{25}$ Inventarse un personaje, una figura de vida sugestiva y apetecible, para un sujeto que no tiene identidad constitutiva, que es futurizo. Una composición de lugar -para una metafísica que aún está tanteando- hecha de imágenes que Ortega solo aprieta con su comprensión del yo como ser ejecutivo: una noción que traslada de la epistemología (con la que se acerca al yo sin la prótesis del ser objetivo, para no cosificarlo) a la metafísica, en tanto que responde a un acto cumpliéndose (verificándose, siendo). ${ }^{26}$ La realidad de mi vida, escribe, consiste en pura ejecutividad, solo en ejecutarse: irse haciendo cada uno a sí mismo. Lo que Ortega llama vocación: un programa íntegro e individual de existencia, que tiene que vérselas con las circunstancias.

Lo explica gráficamente: "La vocación oprime la circunstancia para realizarse en esta. Y la circunstancia responde poniendo condiciones a la vocación en una 
lucha permanente". ${ }^{27}$ Como si fuera su antagonista. Pero la circunstancia de Ortega es siempre un rival asequible (un sparring), que le exige al hombre un esfuerzo, pero que no llega a amenazarlo. Solo una motivación para mostrar el sujeto una actitud moral que él denomina de héroe, o de gentleman, por su enfrentamiento voluntario: "[del] que sabe que tiene que luchar en la vida", escribe. ${ }^{28}$ Un esfuerzo deportivo, que se complace en sí mismo. ${ }^{29}$ Una incisión ética en su planteamiento metafísico que reorienta su tesis hacia la reacción del individuo, ${ }^{30}$ en detrimento de un análisis concienzudo de las condiciones del entorno (que despacha en "Sobre la realidad radical" como una suma de facilidades y dificultades). Al cartografiar su metafísica, Ortega no se ocupa de la fisonomía de la circunstancia, a pesar de ser esta, en su primera formulación, el elemento que le da al yo su entidad completa. No estudia los escenarios posibles, como si su mayor o menor adversidad no fuera determinante en la consecución del programa vital fijado por cada uno. Escribe en ¿Qué es filosofia?: "No se diga, tampoco, que la fatalidad no nos deja mejorar nuestra vida, porque la belleza de la vida está precisamente, no en que el destino nos sea favorable o adverso, ya que siempre es destino, sino en la gentileza con que le salgamos al paso y labremos de su materia fatal una figura noble". ${ }^{31}$ Una actitud optimista, positiva, tan confiada en las fuerzas del individuo que no contempla como opción la derrota (solo la deserción, la renuncia a un proyecto propio, la falta de autenticidad). ${ }^{32}$ Como el cincel, dice, que disfruta al encontrarse la resis- tencia del mármol. ${ }^{33}$ Como si fuera solo una cuestión de tenacidad, de empeño (los rasgos que encuentra en la juventud): De querer vivir. Que significa, en él, esforzarse frenéticamente en vivir. ${ }^{34}$

\section{La circunstancia como rival intratable: la ética de Delibes}

El 11 de septiembre de 1949 le escribe Delibes a Josep Vergés, su editor en Destino, para avisarle del envío del texto mecanografiado de un nuevo libro. Tras el Nadal de 1947 se escriben con frecuencia: al principio porque Delibes, a pesar del premio, se muestra inseguro y confía en Vergés para continuar su carrera literaria. Con su primer intento, El Antracita, también de tema náutico, como la segunda parte de su primera novela, no convence a Vergés, que no llega a publicarlo. En seguida escribe un nuevo texto, que él considera mejor que La sombra del ciprés: más homogéneo, mejor cohesionado, le dice. Vergés lo acepta, pero duda del título, Barro vivo en el original que le ha enviado. A Delibes tampoco le gusta. Le escribe el 24 de septiembre: "En lo tocante al título, coincido con ustedes y, si la llamé así, fue por falta de ideas más sugestivas. Le sugiero como posibles: $E l$ amanecer, Un pobre hombre o Días oscuros, sin que ninguno de ellos me convenza a mí tampoco de manera definitiva. Apreciaría sus opiniones en este sentido, e incluso aceptaría gustoso el que ustedes eligieran como bueno. ¿Qué les parece si no Todos somos de barro?" El 24 de octubre le informa Vergés de la decisión tomada: "Hemos adoptado definitivamente el título Aún es de día que nos daba usted 
como ideal" ${ }^{35}$ Un registro con la correspondencia de ambos que, sin ser exhaustivo, deja al menos seis títulos distintos, con dos enfoques para la novela: uno que prioriza el tema religioso, el peso de lo trascendental, con esa ontología cristiana a la que remite la analogía del barro; y otro que enfatiza la lucha por la vida, sin tener clara la actitud para su perspectiva, con dos posturas contrarias en sus distintas propuestas: una optimista, enérgica, que apunta al principio, al talante con el que afronta cada circunstancia, y otra pesimista, derrotista, que apunta a los resultados, desalentadores: ambas desarrolladas a partir de la misma imagen, con el comienzo y el final del día. Aún es de día, el definitivo, parece quedar a medio camino, con ese aún ambiguo, o al menos indeciso, que refuerza un sentido concesivo para el título, una cierta oposición o cautela al mensaje central de optimismo: Con esa misma disposición temporal de las otras opciones para medir el ánimo, el adverbio pone distancia con ese $a m a-$ necer que desecha antes como título, ${ }^{36}$ menos confiado en la capacidad de recuperación del protagonista, como si vislumbrara el final del día, los síntomas claros del agotamiento (la última escena de la novela, con el protagonista en la cama sin ser todavía de noche), para cuestionar con ese balance último la esperanza inicial de Sebastián Ferrón, que se revela, al menos, como injustificada: "Veinte años llevaba pensando, cada mañana, al despertar, que aquel día podría traerle un cambio radical en su existencia. [...] Se conformaba con anhelarlo, en la esperanza vaga de que fuera algo renovador, algo que le apartase de la triste monotonía de su vida regular y gris", escribe el narrador al comienzo de la historia. ${ }^{37}$

El 26 de abril de 1950 le escribe de nuevo Vergés para comunicarle que el libro apenas se vende, que las librerías lo están devolviendo. El público, le dice, se sigue interesando más por La sombra del ciprés. Delibes se muestra contrariado: "Máxime cuando estimo que es una novela más redonda que la otra y mejor". ${ }^{38}$ Pero poco después, el 5 de septiembre, le avisa a su editor de un nuevo libro que ha escrito en solo unos días en Sedano, mientras descansa en verano con su familia: "Querido amigo: con fecha de hoy le envío una copia mecanografiada de mi nueva novela El camino. Como verá, nada tiene de común con las otras dos, sino, muy al contrario, he pretendido hacer una cosa suave, intrascendente, buscando siempre un punto de equilibrio entre la amenidad y la ternura". ${ }^{39}$ Con el fracaso de Aún es de día reorienta su narrativa, rompe con el dique que le supone esa primera comprensión de la literatura como expresión necesariamente artificiosa, recargada, de tema trascendental. Entiende agotado ese recorrido cuando asume que no ha sido capaz de llevar más lejos su segunda novela que la primera. Pronto reconoce las deficiencias del libro ("su sola lectura me pone de mal humor" le dice a Vergés en 1966, cuando prepara sus Obras completas). Lo toma solo como banco de pruebas, un ejercicio que no debería haber publicado. ${ }^{40}$ Se distancia de él. Y, con él, la crítica, que apenas ha tocado el libro, porque cuesta reconocer en él a Delibes, 
o al mejor Delibes, que es ya el de $E l$ camino, capaz de ahondar en la naturaleza del hombre, al haber acertado con la simbiosis del personaje con su ambiente, casi siempre la Castilla rural, muy empobrecida, para destacar su condición de excluido, de marginado. ${ }^{41}$ Con veinte novelas, algunas fundamentales en la narrativa española del XX, Aún es de día (no tanto La sombra del ciprés) es solo parte del tanteo previo a dar con su estilo. Sin apenas estudios, se da por bueno lo que en un principio se escribió de ella: el enfoque, sobre todo, de Ramón Buckley para el argumento, que carga las culpas en el individuo, por su incapacidad para adaptarse, como si fuera él quien se cree condenado a vivir en soledad, el que se enfrenta a la sociedad para defender su individualidad. Cerca del existencialismo. Como si fuera (solo o principalmente) un problema interno del protagonista, al que Buckley en estas primeras novelas que denomina negativas le hace responsable de su situación, por su hermetismo, por no querer adaptarse. ${ }^{42}$ Pero -con sus limitaciones, con sus deficiencias gravesAún es de día recoge ya su inquietud por el prójimo (el "sentimiento del prójimo", con sus palabras): por la marginalidad, por la falta de solidaridad, por la violencia, o la indiferencia, por el desamor, por el egoísmo, por el aislamiento del individuo. Soporta, más cerca del resto de su narrativa, otra lectura que la del protagonista inadaptado, con la corresponsabilidad del entorno, con la circunstancia en la que se desenvuelve el personaje como factor incapacitante para el cumplimiento de su desarrollo personal.
La descripción de la vida de Sebastián quiere ser el análisis existencial de un acto (fallido) de autoafirmación. Pero el molde de la novela existencial para Aún es de día no es apropiado, o no lo es del todo, a pesar de sus elementos comunes: Demasiado intelectualista, demasiado exigente con la capacidad intelectual del protagonista. Pedro, en La sombra del ciprés es alargada, mejor formado, más reflexivo, encaja mejor con el personaje existencialista, con su individualismo radical, su introversión, su sentimiento de superioridad, su preocupación por la trascendencia o la muerte, con esa tensión mal resuelta entre lo vital y lo intelectual que lastra su existencia; pero Sebastián, muy limitado, sin un discurso sólido, ${ }^{43}$ no tiene el porte que requiere el desarrollo de este tipo de relato, más introspectivo, con el conflicto interiorizado. Tampoco (a pesar de su temática más ajustada, por el peso de lo religioso) como existencialismo cristiano, lejos del desarrollo teórico de Gabriel Marcel, que anduvo en España en 1948, y se le publicó en español, ${ }^{44}$ pero que Delibes no leyó (no hay rastro de ello) o no volcó al menos en su novela, más intuitiva, armada solo con las líneas maestras de la doctrina católica. Aunque a Sebastián (o el temor de Sebastián) lo explica bien la metáfora de la lámpara sin aceite de Marcel, que centra su filosofía en el cimiento ontológico que le da al hombre un cierto número de valores esenciales, como este de la integración del individuo en el grupo. ${ }^{45}$

$\mathrm{Su}$ espacio es el de la narrativa existencial española y europea, a finales de los 40. Pero Aún es de día es más eficaz 
como novela picaresca, modelo que Delibes tiene también cerca, con la publicación en 1942 de La familia de Pascual Duarte. Sabe de una fórmula exitosa, legitimada en su tradición literaria, para mostrar el comportamiento del individuo cuando es excluido, incluso con una finalidad moral, de denuncia ante una sociedad en crisis (la del XVI y XVII pero también la de la España de posguerra). Él propone otra incisión, otros estímulos en la respuesta del protagonista, para protegerlo como sujeto moral; pero sostiene esa estructura propia de la picaresca al darle las características del pícaro a otro personaje, secundario pero vertebral en la trama: Aurelia, la madre de Sebastián, que lo obliga a comportarse como lo haría el pícaro, justificando esa actitud como la única que puede permitirse en un entorno que toma los rasgos de ella, "encajonada en su mugriento agujero, dada al vino y al mal humor", escribe el narrador. ${ }^{46}$ Quiere esa fisonomía para la trama, con un enredo propio de pícaros, al menos con esa apariencia desde el exterior de engaño o de aprovechamiento: Una estructura útil para mostrar esa pelea desigual del individuo con su entorno, con ese mismo punto de partida que la novela picaresca, con ese intento extremo, forzoso, de mejora de las condiciones ruines de vida. Que con Sebastián apuntan a la repetición de la existencia (miserable, frustrada) de su padre, que muere cuando él es un niño, con un determinismo que su matrimonio con Aurora pone en primer plano. Él no se rinde o no se conforma: al contrario, lo toma de estímulo, para, escapando él de su destino, resarcir tam- bién a su padre, al que recuerda llorando por él, "previendo la amargura del camino que aún le quedaba por recorrer". ${ }^{47}$ Delibes vuelve resistente a su personaje, que no se abandona ante las circunstancias sino que lucha con todas sus fuerzas contra lo que tiene a su alrededor, movido solo por la fe, por querer perfeccionar su alma, al contrario que el Lazarillo, o Don Pablos, o Pascual Duarte, al que le basta para justificarse con no haber podido elegir su vida, por habérsela encontrado ya hecha, o al menos determinada. "É se abriría camino, aunque solo fuera para desentumecer la memoria de su padre, su congoja postrera", escribe el narrador de Sebastián. ${ }^{49}$ Pero, como ellos, se ve incapaz: Su madre le imposibilita otra alternativa que la repetición, que la sumisión al camino marcado, haciéndole revivir -o haciéndole ver que no tiene más opción que revivir- la vida de su padre, minándole la confianza como antes se la había minado a este. Como si fuera la antagonista principal en un contexto de obstáculos para la integridad de Sebastián.

Aurelia conmina a su hijo a una actitud hipócrita o cínica, derrotista, dócil con las circunstancias: la misma respuesta del pícaro, también inadaptado, marginado, sin afectos, con la inocencia ultrajada. Le da a Aún es de día la fisonomía de la picaresca con su engaño a Sebastián para casarlo con Aurora, que justifica -cuando es descubierta- en los mismos términos que su matrimonio, con la decisión que tomó ella de joven: "Yo remedié a tu padre sus bajos deseos; él, a mí, mi pobreza. Yo creo que fue un contrato bien equitativo". ${ }^{50}$ Una semejanza que, avan- 
zada la novela, no se le escapa tampoco a Sebastián: "Durante este periodo fue la Aurora para él el futuro remedio de su sensualidad; es decir -ahora se percataba de ello-, lo que fuera Aurelia para su pobre padre, el pedicuro Ferrón, veinticinco años antes". ${ }^{51}$ El final previsible para el pícaro, con su minúsculo (y breve) logro social tras hacerse con los mecanismos de una sociedad que desenmascara como hipócrita, de valores huecos: Aurora, la hija del señor Sixto, adinerada y casquivana, está embarazada de Benjamín Conde, un joven del barrio que no pretende casarse con ella. Para ocultar la vergüenza, la familia de Aurora paga a Aurelia para casarla con Sebastián. A ambas partes les parece un buen trato. El mismo con el que cierra Lázaro de Tormes su autobiografía: "Malas lenguas, que nunca faltaron ni faltarán, no nos dejan vivir, diciendo no sé qué y sí sé qué de que ven a mi mujer irle a hacer la cama y guisalle de comer. Y mejor les ayude Dios, que ellos dicen verdad. Porque, allende de no ser ella mujer que se pague destas burlas, mi señor me ha prometido lo que pienso cumplirá". 52 Un desenlace trillado, recurrente, pero que en Delibes da acceso a un segundo nivel de comprensión, por el ejercicio de introspección del protagonista que pretende hacer de la respuesta un gesto de generosidad, de amor al prójimo: no la solución hipócrita de la picaresca; ni tampoco la contraria, con la reacción airosa de Sebastián al enterarse por su hermana Orencia del engaño, y su decisión de poner fin a su noviazgo, exigiéndole a su madre la devolución del dinero (que desestima luego).
El final, centrado en el perfeccionamiento del alma como único proyecto viable, es un ejercicio de sacrificio que aúna ambas acciones, la boda pero también la abstinencia sexual, ${ }^{53}$ el matrimonio solo como cobijo para el niño. Sebastián, tras la reacción inicial de romper la relación, acaba decidido a casarse con ella, muy afectado por las muertes de la Germana, al suicidarse después de haber intentado ocultar otro embarazo no deseado, y de Benjamín Conde, de un navajazo del Sixto, el hermano de Aurora. Escribe el narrador del desenlace de la novela: "Comprobó, en un segundo, que era esta la misión para la que había sido creado, que él -iqué sarcasmo, Dios mío, para el barrio!- acabaría cerrando el agujero que la Aurora y Benjamín Conde abrieron a medias. Sintió una instintiva repugnancia, pero al pensar en el desgraciado niño por nacer sonrió dolorosamente entre sus lágrimas". ${ }^{54}$ No le queda al protagonista más proyecto vital que perfeccionar su alma. Sin ningún diálogo con su entorno, que Delibes acentúa al quitarle el reconocimiento social de su gesto, al dejar que se malinterprete como egoísta, como la solución del pícaro para medrar a costa de su honra, porque, una vez tomada la decisión, Sebastián es despedido de los almacenes Suárez, lo que refuerza la comprensión desde fuera de su noviazgo como un acto interesado, su conformidad con el acuerdo que habían alcanzado antes ambas familias. Un descrédito que Sebastián acepta con abnegación: "Yo me casaré con ella piense la gente lo que quiera.- Y presentía que era este el verdadero, auténtico, incontaminado sacrificio; 
que solo los actos consumados así, en el secreto de la propia conciencia, son actos meritorios y trascendentes, acreedores, un día, a una eterna contraprestación". ${ }^{55}$

Aún es de día plantea una alternativa al final previsible de la narración de la vida del pícaro. No altera el resultado, con la materialización del camino marcado, con la inminente boda y la adopción del niño. Pero le da otras razones a Sebastián, que piensa solo en un sacrificio para fortalecer su alma, no en salir de la pobreza con el dinero de la Aurora. Sugiere la novela dos niveles de conocimiento: lo que sabe cualquier personaje de la trama y lo que llega a conocer el lector, que puede discernir así las dos vías que llegan a converger en el resultado. Para los personajes, con la información que pueden sacar de los acontecimientos que se narran, con el aspecto exterior de cada acción y su interpretación más intuitiva, el comportamiento de Sebastián es el que cabe esperar del pícaro, el que sacrifica su honor o su honestidad por su bienestar. Pero el lector -mejor informado que los personajes porque el narrador le cuenta también lo que piensa Sebastián- sabe que la razón de su decisión es otra, muy distinta: Que, por tanto, la influencia que el sujeto tiene en la construcción de su entorno, si se resiste a la inercia, es mínima. Uno y otro comportamiento -el del pícaro y el de Sebastián- tienen el mismo aspecto, el mismo espacio en el orden de los acontecimientos, aunque sean dos historias distintas, aunque ese cinismo amargo y resentido con que responde el pícaro al vacío moral que encuentra en su entorno $^{56}$ no tenga nada que ver con Se- bastián. Como si de los distintos elementos de la ecuación la finalidad no afectara al resultado. Con un balance final que es desolador: "El mundo se le venía abajo -escribe el narrador, antes de la respuesta final de Sebastián-. Era como si penosamente hubiese logrado levantar un edificio con las propias manos y le dijesen de súbito: 'Es inútil; todo eso hay que tirarlo; aquí no se puede edificar’. ¡Cuánta privación y cuántos desvelos para nada! Sus sueños absurdos se diluían como por ensalmo; el cuadro de ilusión que poco a poco había ido diseñando se lo emborronaban de pronto con cuatro violentos brochazos". 57

Con todo, el título definitivo de esta segunda novela parece querer sugerir un final positivo, que es también la lectura de algunos de sus críticos, como Pauk, que valora la catarsis del protagonista, ${ }^{58} \mathrm{O}$ Vázquez Fernández, por ser una decisión libre y elegida la repetición de Sebastián de la vida de su padre ${ }^{59}$ o Alvar, por el equilibrio final al que llega Sebastián tras aprender que la vida no puede ajustarse a esquemas rígidos. ${ }^{60}$ Aún es de día como un mensaje esperanzador, con el aún como el indicador de la vigencia de las condiciones iniciales, o de las expectativas iniciales; al menos como envés de esos otros títulos descartados que remiten a la naturaleza del hombre como creación de Dios: el valor relativo de las vicisitudes de la vida al quedar esta relegada a escenario para la preparación del alma para la muerte, atenuada su exclusión social. Así, la decisión última de Sebastián de casarse con Aurora como verdadero, auténtico, incontaminado sacrificio, 
lo redime: repite la vida de su padre, se cumple nítidamente el destino que había intentado rehuir, pero cree darle la vuelta al cambiar los motivos de su casamiento, al utilizarlo como ejercicio para la salvación de su alma.

Pero esa lectura de Aún es de día que toma como clave la redención de Sebastián se construye solo a partir de la comprensión de los acontecimientos que tiene el protagonista, a pesar de que el autor parece desacreditarlo por su escasa inteligencia. No considera la innovación que supone en la narrativa de Delibes el cambio de narrador, la elección de otro personaje, con un punto de vista externo, para narrar la trama y las reacciones de Sebastián: un narrador omnisciente, distinto al protagonista, aunque muy próximo, como si fuera solo una proyección de él mismo, para recoger minuciosamente su pensamiento, saber qué piensa, aunque sin querer para sí una posición privilegiada, propiamente omnisciente con su relato: al tiempo que trascurren los acontecimientos, sin anticiparse nunca, sin permitirse siquiera una reflexión crítica en un segundo nivel, un enjuiciamiento de sus posiciones. Pero al separar al protagonista y al narrador Delibes consigue darle una cierta autonomía a la trama, que conoce el lector no a través de Sebastián, al vivirla él mismo, sino de un narrador que parece querer mostrarse objetivo. Enseña al lector de un lado los motivos de Sebastián y de otro el aspecto exterior o social de sus actos, de su decisión, para no cargar el significado de la novela tanto en los planteamientos de su protagonista (con esa lectura más cercana a la literatura y la filosofía exis- tencialistas) como en su aspecto social, en la malinterpretación o incomprensión de su decisión. Le da al lector la posibilidad de comparar la actitud del protagonista con los hechos, la vida de santo que pretende para sí y la vida de pícaro que parece insinuar su noviazgo.

Con una mayor credibilidad que Sebastián, por su condición de omnisciente, el narrador relata el resultado penoso que trasmite Delibes en estos primeros trabajos: la incapacidad del sujeto para hacer frente a una circunstancia decididamente adversa: Sebastián, aunque lo justifique como un acto de generosidad, acaba cumpliendo (o decidido a cumplir) el proyecto de su madre y de la familia de Aurora: no hay diferencias entre su actuación y la del pícaro, la pensada para engañarlo, acentuándose, con su despido de los almacenes Suárez, los motivos que desde fuera justificarían su boda y la aceptación del niño. Su papel es o parece el del pícaro (o el del burlado). Solo el lector -con un conocimiento privilegiado por tener acceso a la información del narrador- sabe de las intenciones de Sebastián, de su condición moral, opuesta a la del pícaro, y por tanto de la insignificancia de su decisión en los acontecimientos, para testar la tesis del primer Delibes, para entender la biografía desgraciada de Sebastián como ejemplo negativo, como consecuencia de querer enfrentarse a las circunstancias en lugar de aceptar resignado los acontecimientos: lo que llega a plantearse él mismo con su noviazgo con la Aurora, antes de recuperar fuerzas de nuevo: "Tal vez sea lo mejor dejar que las cosas vengan a moverse y no intentar yo mover las cosas". ${ }^{61}$ 
Con su selección de los acontecimientos en la biografía de Sebastián, comprimidos en pocas semanas, como si fuera la jornada a la que parece referirse el título, el narrador derriba las expectativas iniciales del protagonista, la ilusión que le genera su nuevo empleo y el noviazgo con Aurora. Primero con ese aviso que es la rotura de la luna de un escaparate en la celebración del ascenso de Sebastián, cuando sus compañeros le hacen creer que ha sido él el que la ha roto y tiene que pagarla, esa vuelta a la realidad ("Volvía la multitud a convertirse en un monstruo para Sebastián"), ${ }^{62}$ y las primeras sospechas con Aurora, inmediatamente después, por su viaje a Madrid y su carácter irascible. ${ }^{63}$ Como si el protagonista, a pesar del esfuerzo, fuera incapaz de ir haciendo frente a todos los reveses, de encontrar su espacio. Con los primeros golpes, Sebastián redescubre la religión, la fe, primero, mediada la novela, como vía de escape (con la tentación de recluirse en el convento, y abandonar así su vida, evadirse tras los muros de la iglesia como si fueran un paréntesis), ${ }^{64} \mathrm{y}$ después como estímulo para intentar darle de nuevo sentido a su vida, para darle otra dirección, para retomar su proyecto vital con las fuerzas recobradas con su fe. ${ }^{65}$ Enfocada cada acción a pulir su alma y prepararse para la muerte (para el hombre que sufre y que lucha, el universo tiene un sentido, dice Marcel). Reorienta su vida, o pretende reorientarla, sustituyendo un proyecto vital, más social, de adaptación al medio, por otro, de orden espiritual. Con un nuevo programa que implica la ruptura del diálogo con su en- torno, al menos en uno de los sentidos, en tanto que el entorno deja de afectarlo, porque no encuentra otra vía para su desarrollo que escindir el alma del cuerpo, que renunciar a la posibilidad de un proyecto para su vida en comunicación con sus circunstancias, tan hostiles. Aunque le quedan más adversidades; al menos una, para probarse definitivamente: El engaño pactado entre Aurelia y la familia de Aurora, en el que él acepta finalmente ser la víctima, el sacrificado. Un último intento de darle un sentido, un objetivo, a su vida: más dueño de sí que nunca, escribe el narrador, ${ }^{66}$ a pesar de esa última escena tras su despido, derrumbado en la cama, de vuelta de sus ensoñaciones, confrontado con el bullicio del barrio: "Sobre el fondo de aquella algarabía apenas si se oyó el desgarrado sollozo de Sebastián". ${ }^{67}$

Con Sebastián Ferrón, en su segunda novela, Delibes quiere una alternativa a la conducta de Pedro. La sombra del ciprés es alargada, más rígida, con una trama para la vida del protagonista más encorsetada, es a un tiempo novela de tesis y de formación: la encarnación con Pedro del principio de desasimiento, del intento de no verse afectado por el peso de la muerte sobre la vida. Huérfano, Pedro aprende de su maestro, Mateo Lesmes, que la clave de la felicidad está en quedarse en poco, para no temer perderlo: no crear vínculos, un distanciamiento frío con la vida. Un pesimismo que cala pronto en él, como la culminación de su formación, como síntoma de su madurez intelectual. Escribe de cuando tenía trece años: "Presentí que comenzaba a hacerme hombre por dentro 
[...]. Y noté que quien me había despertado era mi maestro con sus bien centradas palabras sobre la felicidad. Mi cabeza ya podía dilucidar entre la dicha y la desdicha. Sus circunvoluciones actuaban ahora bajo el riego de una substancia que secretaba la razón. [...] Y todo ello se lo debía a la fría exposición de don Mateo. Había asimilado su lección en todas sus facetas, sus determinantes y sus consecuencias. Sus palabras se habían volcado sobre mi ser, empapándole como si fuese una esponja". ${ }^{68}$ Adecua su vida a la teoría del desasimiento, traumatizado de niño con la muerte de Alfredo, su amigo. Le tienta, como a Sebastián, la vida religiosa, para apartarse del mundo, ${ }^{69}$ pero opta al final por hacerse marino mercante, que, piensa, “conservándome en el mundo, me permitía al propio tiempo mantenerme apartado de él" ${ }^{70}$ Con los años, alejado de la casa de Mateo Lesmes, llega a cuestionarse esa obsesión por la muerte. Recula. Entiende que se ha equivocado: "Comprendí -se dice- que me había formado erradamente; que no había razón de vida fuera de la vida misma; que me hallaba en franca y abierta oposición con el mundo; un mundo denso, olvidadizo, que se reía de mis ridículos temores". ${ }^{71}$ Inicia su noviazgo con Jane, una norteamericana que conoce en Providence. Se casa, pero regresa solo a España, en un último viaje de trabajo. Se reencuentra en Bilbao con Martina, hija de Lesmes, con su vida arruinada por el empecinamiento de su padre al educarla. Vuelve a su casa, en Ávila, para llevarla de vuelta. Allí le reconoce su maestro que estaba equivocado, que esa premisa suya de que era posible desvincularse de todo para no sufrir era falsa, que siempre hay mucho que perder. ${ }^{72}$ Jane le anuncia por carta que está embarazada. Habla también con la suegra de Bolea, su compañero: "Alimentados de pesimismo no vivimos la vida, la sufrimos. Todo lo malo de la vida se agiganta para el pesimista, y, además, lo bueno lo hace malo, precisamente porque de todo escoge su fachada negativa" ${ }^{73}$ Todo apunta a un cambio de actitud, a otro modo de enfrentarse a la vida, sin miedo a atarse. Con la terminología de la dialéctica: la antítesis tras la tesis, la réplica, con el refuerzo del propio Lesmes, convertida la novela en una argumentación. Pero Jane muere en un accidente, en el puerto de Providence: cae su coche al mar, después de ser golpeado por una vagoneta. Pedro, que llega en barco, ve cómo se hunde y cómo luego sacan el cadáver. De inmediato vuelve al principio, a la convicción de su maestro sobre las bondades del desasimiento: "Comencé a gustar de nuevo la angustia desoladora de sentirme impar sobre la costra de la tierra; de hallarme aislado, sin eslabones afectivos, sin un sólido y macizo punto de apoyo. [...] Pensé que nada me quedaba fuera de mí, que la discordancia del mundo con mi yo era ahora total, absoluta, sin nada ni nadie que mitigase el desamparo de mi cerrada soledad". ${ }^{74}$ Se agudiza su fe, su esperanza en la vida tras la muerte. Vuelve a Ávila, para terminar el relato con un último gesto de su apartamiento del mundo: Introduce el anillo de Jane en la tumba de Alfredo, para unir a sus dos seres queridos, sus dos grandes afectos.

La reflexión última, que parece querer funcionar de síntesis, es confusa: feliz, o 
al menos confiada o relajada al cerrar esa etapa, al alejarse del cementerio, porque tira de ella de nuevo lo religioso, su fe en Dios, justificada (o reforzada) esa voluntad de desasirse del mundo (con el que acaba por no reconciliarse) en la condición mortal del hombre. Escribe: "Se me hacía que ya había encontrado la razón suprema de mi pervivencia en el mundo. Ya no me encontraba solo. Detrás dejaba a buen recaudo mis afectos. [...] Tropecé con un obstáculo oculto por la nieve. Al mirar hacia el suelo comprobé que a la nieve la hace barro el contacto con el pie...". ${ }^{75}$ Obtuso con las claves del balance, pero con la referencia final al barro como justificación de su trayectoria vital, amarrada su comprensión de la naturaleza del hombre a la ontología cristiana: una imagen con la que amaga varias veces también en Aún es de día, el origen del tema de ambas novelas.

Pero detrás de ese primer nivel de información con el contenido con el que reflexiona Delibes, queda ese segundo nivel que la intervención del narrador en cada caso determina. En La sombra del ciprés es alargada el narrador -que es el protagonista, que escribe su historia pasado el tiempo- busca corroborar su teoría, adecuar los acontecimientos a esa idea del desasimiento con la que moldea su trayectoria vital. Con su perspectiva no hay fricción entre las circunstancias y la voluntad del personaje: ajusta el recuerdo de su conducta ante cada eventualidad, limadas por el paso del tiempo las aristas de los acontecimientos en su vida, que interpreta en su conjunto, como una línea argumental coherente que superpo- ne a su biografía la teoría asimilada desde su infancia, que le funciona de guía (y de límite, muy restrictiva). Con su enfoque pretende pasar por alto su confrontación con las circunstancias. El relato no incide en el enfrentamiento, en las dificultades que le pone el entorno (a pesar de su vida difícil). Al contrario: con cada revés enseguida el narrador encuentra una respuesta afirmativa (la aceptación y el valor que trae consigo el revés). Como si buscara una biografía redonda: en último término una justificación de sí mismo, de su comportamiento (con su amago de conversión y la corroboración de su actitud tras la segunda pérdida). En cambio, el narrador de la historia de Sebastián, a pesar de la empatía que parece sentir por él, o de su actitud acrítica, no busca justificarlo, no pretende redondear su historia, con lo que no rehúye los enfrentamientos del protagonista con su entorno: al contrario, incide en ellos, para presentar a Sebastián como víctima, como marginado. Una diferencia que Delibes no parece querer destacar, secundaria respecto al tema que comparten ambas novelas, con su estructura circular, de vuelta al principio, pero que le supone a la segunda la posibilidad de introducir en el contexto de la narrativa española de los años $40 \mathrm{y}$ 50 una réplica al optimismo vitalista de Ortega.

La biografía de Sebastián es una cartografía con los obstáculos, con una actitud el narrador que es la que Ortega reconoce en la literatura picaresca, por la que no llega a interesarse nunca. Un desinterés que explica en "Una primera vista sobre Baroja", que escribe muy joven, en 
1910, aunque no lo publica hasta 1915: "La novela picaresca es en su forma extrema una literatura corrosiva, compuesta con puras negaciones, empujada por un pesimismo preconcebido, que hace inventario escrupuloso de los males por la tierra esparcidos, sin órgano para percibir armonías ni optimidades". ${ }^{76}$ En la narrativa posterior de Delibes sus personajes ganan seguridad en sí mismos. Su actitud es otra que el enfrentamiento frontal con una sociedad que los deja fuera, porque el autor no les impone ese determinismo que hace inviable cualquier iniciativa de los protagonistas, aunque sus rasgos, con pocas excepciones, sean los de Pedro y Sebastián: marginados, pobres, víctimas, por la falta de amor y solidaridad. Pero en sus primeras novelas la relación del individuo con la sociedad queda fuera de esos márgenes de lo razonable que plantea Ortega. Para María Isabel Vázquez Fernández, por el momento histórico en que escribe Delibes estas novelas, el escepticismo de la España de la inmediata posguerra. ${ }^{77}$ Extendido el sentido del balance de la vida de Sebastián (con su actitud y sus resultados) al conjunto de la sociedad: "Cada día se despertaba uno con una nueva ilusión y cada noche la ilusión se trocaba en un amargo desengaño. Pero el cúmulo de desilusiones y desengaños, de reveses y contrariedades, no conseguía matar del todo la esperanza general de que ya estaba al alcance de la mano la anhelada liberación de la implacable y mezquina tiranía de la cartilla de racionamiento" ${ }^{78}$ Otro modo de hacer novela social, o (si queremos evitar la clasificación) al menos con una inquietud social: crítica, con el relato de un conflicto ostentosamente humano (con la expresión de Jordi Gracia para la novela neorrealista) ${ }^{79}$ que no esconde su cobertura política. Hecha de sujetos que la cultura oficial intentaba esconder. Para Delibes antihéroes ${ }^{80}$ porque con esas circunstancias el único proyecto que cabe es una vía de escape, renunciar a todo apoyo externo para buscarse a sí mismo; aunque para Ortega -que buscaba en otra dirección- esa sea su definición de héroe: ser uno mismo, resistirse a que lo circunstante imponga unas acciones determinadas, para asentar solo en uno mismo el origen de sus actos (I, 816 ss.). ${ }^{81}$

\section{BIBLIOGRAFÍA}

Alonso de los Rios, C., Conversaciones con Miguel Delibes, Magisterio Español, Madrid, 1971.

Alvar, M., El mundo novelesco de Miguel Delibes, Madrid, Gredos, 1987.

Anónimo, La vida de Lazarillo de Tormes y de sus fortunas y adversidades, Akal, 1997.

Aranguren, J.L., La ética de Ortega, Taurus, Madrid, 1966.

Barrero, O., La novela existencial española de posguerra, Gredos, Madrid, 1987.

Buckley, R., Problemas formales en la novela española contemporánea, $\mathrm{Pe}-$ nínsula, Barcelona, 1968.

Cela, C. J., La familia de Pascual Duarte, Seix Barral, Barcelona, 1984.

Cerezo Galán, P., Ortega y Gasset y la razón práctica, Biblioteca Nueva, Madrid, 2011.

Delibes, M., La sombra del ciprés es alargada, Biblioteca El Mundo, Madrid, 2001 ( $1^{\text {a }}$ edición: 1947). 
Delibes, M., Aún es de día, Destino, Barcelona, 1994 ( $1^{a}$ edición: 1949).

Delibes, M., Pegar la hebra, Destino, Barcelona, 1991 ( $1^{a}$ edición: 1990).

Delibes, M., España 1936-1950: muerte y resurrección de la novela, Destino, Barcelona, 2004.

Delibes, M. y Vergés, J., Correspondencia, 1948-1986, Destino, Barcelona, 2002.

Gracia, J., Estado y cultura. El despertar de una conciencia crítica bajo el franquismo, 1940-1962, Anagrama, Barcelona, 2006.

Lasaga Medina, J., Figuras de vida buena, Enigma editores, Madrid, 2006.

Marcel, G., El misterio del ser, Edhasa, Barcelona, 1971.

Marías, J., "La novela como método de conocimiento", La escuela de Madrid, Buenos Aires, Emecé Editores, 1959.

Molinuevo, J.L., El sentimiento estético de la vida, Tecnos, Madrid, 1995.

Parker, A., Los pícaros en la literatura. La novela picaresca en España y Europa (1599-1753), Gredos, Madrid, 1975.

Pauk, E., Miguel Delibes: desarrollo de un escritor (1947-1974), Madrid, Gredos, 1975.

Ortega y Gasset, J., "Una primera vista sobre Baroja", Obras completas II, Taurus, Madrid, 2004 ( $1^{\mathrm{a}}$ edición: 1910).

Ortega y Gasset, J., "Ensayo de estética a manera de prólogo", Obras completas I, Taurus, Madrid, 2004 ( $1^{\mathrm{a}}$ edición: 1914).

Ortega y Gasset, J., Meditaciones del Quijote, Obras completas I, Taurus, Madrid, 2004 (1ª edición: 1914).
Ortega y Gasset, J., Personas, Obras, Cosas, Obras completas II, Taurus, Madrid, 2004 (1ª edición: 1916).

Ortega y Gasset, J., "No ser hombre ejemplar", Obras completas II, Taurus, Madrid, 2004 (1 ${ }^{\mathrm{a}}$ edición: 1924).

Ortega y Gasset, J., La deshumanización del arte e Ideas sobre la novela, Obras completas III, Taurus, Madrid, 2005 ( $1^{\mathrm{a}}$ edición: 1925).

Ortega y Gasset, J., Meditación de nuestro tiempo, Obras completas VIII, Taurus, Madrid, 2008 ( $1^{\mathrm{a}}$ edición: 1928).

Ortega y Gasset, J., ¿Qué es filosofía?, Obras completas VIII, Taurus, Madrid, 2008 ( $1^{\mathrm{a}}$ edición: 1929).

Ortega y Gasset, J., "Prólogo a una edición de sus obras", Obras completas V, Taurus, Madrid, 2006 ( $1^{\mathrm{a}}$ edición: 1932).

Ortega y Gasset, J., "Pidiendo un Goethe desde dentro -Carta a un alemán", Obras completas V, Taurus, Madrid, 2006 ( $1^{a}$ edición: 1932).

Ortega y Gasset, J., "Meditación de la técnica", Obras completas V, Taurus, Madrid, 2006 ( $1^{\text {a }}$ edición: 1939).

Ortega y Gasset, J., "El hombre y la gente [Curso de 1939-1940]", Obras completas IX, Taurus, Madrid, 2009 ( $1^{a}$ edición: 1939$)$.

Ortega y Gasset, J., "Prólogo a Veinte años de caza mayor del conde de Yebes", Obras completas VI, Taurus, Madrid, 2006 (1 $1^{\mathrm{a}}$ edición: 1942).

Vázquez Fernández, Ma.I., Miguel Delibes, el camino de sus héroes, Pliegos, Madrid, 2007.

\section{NOTAS}

${ }^{1}$ Delibes, M., Aún es de día, Destino, Barcelona, 1994, 282.

${ }^{2}$ Centrado en sus oposiciones, su modelo es el manual de Joaquín Garrigues. Escribe en España 1936-1950: muerte y resurrección de la novela (Destino, Barcelona, 2004, 159): "Por debajo de las aburridas teorías jurídicas, yo encontré en él la belleza, la gracia, y la exactitud expresivas [...]. Garrigues, a mi entender, no fue solo un gran maestro, sino un excelente escritor. A partir de él, empecé a tomar gusto a la expresión verbal y, por primera vez en la vida, experimenté el placer de encadenar unas palabras a otras para formular con precisión una idea". Lo compara, de hecho, con Ortega y Gasset en Pegar 
la hebra (Destino, Barcelona, 1991, 144): “A algunos escritores de mi tiempo esta fascinación se la produjo Ortega y aun cuando, posteriormente, se repitió esta emoción ante algunos ensayos del maestro, la primacía se la debo a don Joaquín [Garrigues] -muy orteguiano por cierto-"

${ }^{3}$ Ortega y Gasset, J., "Pidiendo un Goethe desde dentro -Carta a un alemán", Obras completas, Taurus, Madrid, 2004-2010, V, 122.

${ }^{4}$ Ortega y Gasset, J., "El hombre y la gente [Curso de 1939-1940]", Obras completas, cit., IX, 296.

${ }^{5}$ Escribe Aranguren, como preámbulo de su explicación del desarrollo como ética de la metafísica de Ortega: "La formulación de la ética orteguiana es insuficiente porque Ortega nunca escribió ni se propuso escribir un libro de ética. Nada, pues, más natural que la existencia de lagunas a este respecto en su obra". Cf. Aranguren, J.L., La ética de Ortega, Taurus, Madrid, 1966, 54.

${ }^{6}$ Ortega y Gasset, J., La deshumanización del arte e Ideas sobre la novela, Obras completas, cit., III, 903.

${ }^{7}$ Marías, J., "La novela como método de conocimiento", La escuela de Madrid, Buenos Aires, Emecé Editores, 1959, 328-344.

${ }^{8}$ Escribe: "La ética que acaso el año que viene exponga en un curso ante ustedes se diferencia de todas las tradicionales en que no considera al deber como la idea primaria en la moral, sino a la ilusión". Cf. Ortega y Gasset, J., ¿Qué es filosofia?, Obras completas, cit., VIII, 363.

9 Ortega y Gasset, J., "Pidiendo un Goethe...", Obras completas, cit., V, 140.

${ }^{10}$ Delibes, M., Aún es de día, op. cit., 199.

${ }^{11}$ Aranguren, J.L., op. cit., 31 y 48.

${ }^{12}$ Lasaga Medina, J., Figuras de vida buena, Enigma editores, Madrid, 2006, 194.

${ }^{13}$ Cerezo Galán, P., Ortega y Gasset y la razón práctica, Biblioteca Nueva, Madrid, 2011, 203.

${ }^{14}$ Ortega y Gasset, J., "No ser hombre ejemplar", Obras completas, cit., II, 478.

${ }^{15}$ En 1908, en "Sobre El Santo", Rubín de Cendoya presenta la estética espacial como un arte más, con la disposición de algunos edificios, pero que no se reduce a la arquitectura. Es -señala- la capacidad, tras siglos de idealismo, de llegar a percibir lo sensible, del ver del hombre mediterráneo, amante acérrimo de las cosas sensibles, enemigo de todo lo trascendente a la materia; impresionista, porque busca lo sensible como tal. Cf. Ortega y Gasset, J., Personas, Obras, Cosas, Obras completas, cit., II, 22-23.

${ }^{16}$ Cerezo Galán, P., op. cit, 72 y 88.

${ }^{17}$ Ibid., 111-112.

18 "Como un actor que se despierta de pronto en un escenario y debe improvisar delante del público", escribe en ¿Qué es filosofía? (cit., VIII, 356).

${ }^{19}$ Ortega y Gasset, J., Meditaciones del Quijote, Obras completas, cit., I, 756.

${ }^{20}$ Ibid., I, 757.

${ }^{21}$ Ibid., I, 754.
${ }^{22}$ Pensar el sujeto trascendental junto a su circunstancia es devolverlo al mundo, escribe Ortega como resumen en "Pidiendo un Goethe desde dentro" (1932).

${ }^{23}$ Escribe en ¿Qué es filosofía?, en 1929: "Nuestra vida es nuestro ser. Somos lo que ella sea y nada más -pero ese ser no está predeterminado, resuelto de antemano, sino que necesitamos decidirlo nosotros, tenemos que decidir lo que vamos a ser" (cit., VIII, 357).

${ }^{24}$ Ortega y Gasset, J., "Prólogo a Veinte años de caza mayor del conde de Yebes", Obras completas, cit., VI, 272.

${ }^{25} \mathrm{Cf}$. Molinuevo, J.L., El sentimiento estético de la vida, Tecnos, Madrid, 1995, 13.

${ }^{26}$ Escribe en 1914 (aunque no vuelve a retomar esta idea): "Yo significa, pues, no este hombre a diferencia del otro, ni mucho menos el hombre a diferencia de las cosas, sino todo -hombres, cosas, situaciones-, en cuanto verificándose, siendo, ejecutándose”. Cf. Ortega y Gasset, J., "Ensayo de estética a manera de prólogo", Obras completas, cit., I, 668.

${ }^{27}$ Ortega y Gasset, J., "Prólogo a una edición de sus obras", Obras completas, cit., V, 96.

${ }^{28}$ Ortega y Gasset, J., "Meditación de la técnica", Obras completas, cit., V, 581.

${ }^{29}$ Ortega y Gasset, J., "Prólogo a Veinte años...", op. cit., VI, 313.

${ }^{30}$ Escribe en Meditación de nuestro tiempo: "Lo mejor es aceptarla alegremente, reconocer que con ella nos es dado el tema para una creación" (Obras completas, cit., VIII, 50).

${ }^{31}$ Ortega y Gasset, J., ¿Qué es filosofia?, op. cit., VIII, 372

32 "Nada debilita tanto los profundos resortes del viviente como el exceso de facilidades", escribe. Cf. Ortega y Gasset, J., "Pidiendo un Goethe...", Obras completas, cit., V, 140.

${ }^{33}$ Ortega y Gasset, J., ¿Qué es filosofia?, op. cit., VIII, 371-372.

${ }^{34}$ Ibid, VIII, 248.

${ }^{35}$ Delibes, M. y Vergés, J., Correspondencia, 1948 1986, Destino, Barcelona, 2002, 62-64.

36 "Era este, para Sebastián, el único momento feliz del día", cuenta el narrador. Cf. Delibes, M., Aún es de día, cit., 9 .

${ }^{37}$ Delibes, M., Aún es de día, cit., 9.

${ }^{38}$ Delibes, M. y Vergés, J., op. cit., 74.

${ }^{39}$ Ibid., 75 .

${ }^{40}$ Escribe en España 1936-1950: Muerte y resurrección de la novela (cit., 160). "A mí me faltó el pudor porque carecía aún de sentido crítico. Esta es la razón de que mis dos primeras novelas -La sombra del ciprés es alargada y Aún es de día- vieran la luz, cuando, dentro de un proceso normal de maduración, venían a representar los ejercicios primerizos de un aspirante a escritor y, como tales, unas obras de tanteo y exploración escritas para ser destruidas. De ahí que me resista a considerar estas obras, toscas e inmaduras, como la primera etapa de mi quehacer narrativo, a no 
ser que merezca la consideración de etapa el periodo del despertar, el aprendizaje y los coscorrones". A César Alonso de los Rios le confiesa en Conversaciones con Miguel Delibes (Magisterio Español, Madrid, 1971, 116): "Se trata de una historia sentida, indudablemente, pero de un trazo burdo, de un naturalismo muy desabrido y de un humor -por designarlo de algún modo- de mal gusto, de una tosquedad inefable".

${ }^{41}$ En 1965, en una conferencia en el Ateneo de Madrid, dice el propio Delibes: "Yo me disfracé para escribir mis dos primeras novelas, solo a partir de $E l$ camino fueron mis obras fruto de mi personalidad."

${ }^{42}$ Ramón Buckley distingue, por su temática y estilo, dos etapas en Delibes. Escribe de la época "negativa" en Problemas formales en la novela española contemporánea (Península, Barcelona, 1968, 90-91): "El protagonista (hombre-individuo) se enfrenta a la sociedad (o sea al 'hombre-masa') y defiende su 'individualidad' que la sociedad trata de quitarle: $L a$ sombra del ciprés es alargada, Aún es de día, Mi idolatrado hijo Sisi." Y de la época "positiva": "El protagonista (hombre-individuo) se adapta a una sociedad formada por otros 'hombres-individuos' y se rebela si se le quiere llevar a una sociedad de hombres-masa: El camino, los dos Diarios, La hoja roja, Las ratas y La mortaja (Siestas con viento Sur)."

${ }^{43}$ Lo piensa al menos el narrador, que escribe con la novela ya muy avanzada: "A veces llegaba a nimiedades ingenuas, sugeridas por las lecturas de libros de santos adaptadas a mentes infantiles. Él, en realidad, había vivido poco y apenas sabía nada fuera de lo que se encerraba en aquellos libros, los primeros que empezaron a fertilizar su inteligencia". Cf. Delibes, M., Aún es de día, cit., 256.

${ }^{44}$ En 1948 impartió en Madrid una serie de conferencias, que tuvo, como ha escrito Óscar Barrero ( $\mathrm{La}$ novela existencial española de posguerra, Gredos, Madrid, 1987, 24), cierta repercusión en la prensa. Se publicaron dos artículos suyos en La Hora, en los números 31 (el 3 de junio de 1949) y 72 (3 de diciembre de 1950).

${ }^{45}$ Escribe en El misterio del ser: "Cada uno de nosotros sin duda puede y debe preguntarse [...] ¿de qué vives tú? Se trata no solo del fin hacia el cual nuestra vida se ordena, sino más bien del combustible mental que nos permite continuar. Sabemos demasiado que hay seres desesperados que languidecen y se consumen como lámparas sin aceite". Cf. Marcel, G., El misterio del ser, Edhasa, Barcelona, 1971, 76.

${ }^{46}$ Delibes, M., Aún es de día, cit., 66.

${ }^{47}$ Ibid., 27.

48 Escribe Cela para la justificación de Pascual Duarte: "Yo, señor, no soy malo, aunque no me faltarían motivos para serlo. Los mismos cueros tenemos todos los mortales al nacer y sin embargo, cuando vamos creciendo, el destino se complace en variarnos como si fuésemos de cera y en destinarnos por sendas diferentes al mismo fin: la muerte [...] Hay mucha diferencia entre adornarse las carnes con arrebol y colonia, y hacerlo con tatuajes que después nadie ha de borrar ya". Cf. Cela, C. J., La familia de Pascual Duarte, Seix Barral, Barcelona, 1984, 21.

${ }^{49}$ Delibes, M., Aún es de día, cit., 30.

${ }^{50}$ Ibid., 27.

${ }^{51}$ Ibid., 146.

52 Anónimo, La vida de Lazarillo de Tormes y de sus fortunas y adversidades, Akal, 1997, 133.

${ }^{53}$ Por pensar que es la sexualidad el peor enemigo de la Humanidad: "Constató que lo que amenazaba la colectiva existencia, abrazándola en un cerco asfixiante, era la más brutal, ruin y descarnada sensualidad". Cf. Delibes, M., Aún es de día, cit., 275.

${ }^{54}$ Delibes, M., Aún es de día, cit., 297.

${ }^{55}$ Ibid., 304.

${ }^{56}$ Parker, A., Los pícaros en la literatura. La novela picaresca en España y Europa (1599-1753), Gredos, Madrid, 1975, 53.

${ }^{57}$ Delibes, M., Aún es de día, cit., 276.

${ }^{58}$ Cf. Pauk, E., Miguel Delibes: desarrollo de un escritor (1947-1974), Madrid, Gredos, 1975.

${ }^{59}$ Vázquez Fernández, Mª.I., Miguel Delibes, el camino de sus héroes, Pliegos, Madrid, 2007, 228.

${ }^{60}$ Cf. Alvar, M., El mundo novelesco de Miguel Delibes, Madrid, Gredos, 1987.

${ }^{61}$ Delibes, M., Aún es de día, cit., 148.

${ }^{62}$ Ibid., 93.

${ }^{63}$ Ibid., 103.

${ }^{64}$ Ibid., 154

${ }^{65}$ Escribe: "Cabía hacerse un hombre completamente diferente, con una misión y un objetivo definido y escueto. El alma era lo primero y era el alma precisamente lo que le brindaba la ocasión de transformarse". Cf. Delibes, M., Aún es de día, cit., 231.

${ }^{66}$ Ibid., 304.

${ }^{67}$ Ibid., 307.

${ }^{68}$ Delibes, M., La sombra del ciprés es alargada, Biblioteca El Mundo, Madrid, 2001, 65-66.

${ }^{69}$ Ibid., 134.

${ }^{70}$ Ibid., 136

${ }^{71}$ Ibid., 158.

${ }^{72}$ Ibid., 219.

${ }^{73}$ Ibid., 238.

${ }^{74}$ Ibid., 280

${ }^{75}$ Ibid., 286-287.

${ }^{76}$ Ortega y Gasset, J., "Una primera vista sobre Baroja", Obras completas, cit., II, 260.

${ }_{77}$ Vázquez Fernández, Ma..I., op. cit., 198-199.

${ }^{78}$ Delibes, M., Aún es de día, cit., 233.

${ }^{79}$ Gracia, J., Estado y cultura. El despertar de una conciencia crítica bajo el franquismo, 1940-1962, Anagrama, Barcelona, 2006, 207.

${ }^{80}$ Alonso de los Rios, C., op. cit., 108.

${ }^{81}$ Ortega y Gasset, J., Meditaciones del Quijote, op. cit., I, 816 ss. 